\section{DIGITAL ADDICTION: THE CULTURAL PRODUCTION OF ONLINEAND VIDEO GAME JUNKIES}

\begin{abstract}
This paper examines the ways in which a concept of 'digital addiction' is produced in This paper examines the ways in which a concept of 'digital addiction' is pilture. Digital addiction is used academic discourse, news media and contempora internet/online addiction and addiction to here as a collective term for the phenomena of interned individually and together in the electronic games. By showing how these are produced individich the digital is likened to popular imaginary, the paper explores several of the ways in which the dissociation is made through chemical, illicit or hallucinogenic drugs. It is shown that oversimplified representation of normative discourses which work through a reductive and oversimplified representalion of is represented as dangerous, false and addictive.
\end{abstract}

Moral panics around compulsive and addictive use of digital media have emerged Moral parious platforms of new media every few years technology, including predominantly the internet, electromic games and most recently mobile telephony. The release of Kimberly Young's 1998 pop psychology text Caught in the Net: How to Recognize the Signs of Internet Addiction - and a Winning Strategy for Recovery caused a considerable media flurry about overa Winning Strategy for Recovery causedic 'confessions' of mternet addiction. More use of the internet and a num recently, an article run in January 2004 in both the Sydney Morning Herald (Sydney) and The Age (Melbourne) described the research imto the psychological health of 'online addicts' by Mattias Jerusalem of the Humboldt Umiversity of health of 'online addicts' Berlin. The

Popular and news media representations of digital addiction draw significantly on media releases regarding academic research which, for the most part, is on media relos technology and educational pedagogy conducted in psyched Young's mitial work departments. Several writers have supported or extended Young's intial work, although others have used psychodynamic research methods to suggest that there is nothing specifically addictive about electronic gaming as an activity (Egli, 1984). is nothe behaviourist research has sought to show a link between mternet or video Some behaviourist research has sought to seleem or multiply-addictive personalities gaming addiction and pro
(Greenberg et al., 1999).

cause addiction remains a moot poimt from the perspective of media and cultural theory, partly because it replicates a from the relationship between behaviour and new media, and partly because it represents the individual utilisation of both electronic games and the internet as level and homogenic. I am arguing in this paper that digital media forms are by no means addictive in and of themselves, and that the representation of digital cultural products as addictive relates to understandings that attempt to install digital media within arguments that support an artificial divide between the 'real' and the 'virtual', or the 'natural' and the 'technological'.

The assertion that new media are addictive is produced in such a way that the conceptual and imaginative spaces of both games and various internet documents and activities are given as the unlenown, dangerous, unsafe or menacing, with strong similarity to the discursive representation of chemical drugs. I have no doubt that there are many social problems associated with spending excessive time online or in compulsive use of electronic gaming (whether solo, with others physically present or in online gaming). But, as John Grohol neatly puts it: 'Socializing with a friend, reading a book, work and watching television are [also] all activities which people enjoy but sometimes take to an extreme.' (Grohol, 2000: 140) It is the specificity of digital worlds as they are imagined in popular culture, news media and certain strands of academic ego-psychology discourses that provides digital environments with a set of significations making them on the one hand somehow 'less than real' (virtual) and on the other hyper-real negative environments which are understood to be addictive in and of themselves.

I discuss firstly the politics of applying a rhetoric of addiction to frequent/ excessive use of digital media forms, before going on to address the ways in which internet addiction has been represented in academic and media discourses, and particularly in the pop psychology of online addiction guru Kimberly Young (1997, 1998, 2003). I will follow with an examination of the rhetoric of video gaming addiction that collapses the question of frequency of use with addiction, violence, play, competitiveness, tension and questions of the 'loss of the self'. Finally, by drawing on an interview given by Jacques Derrida on drug addiction, I want to show how the meaning of talk and debate about addiction works to represent both games and the internet as purely simulacral, unreal and unnatural, thereby locating them together in an unproductive and under-theorised real/virtual dichotomy. I am particularly interested in dealing together with two representations of digital addiction (internet and electronic gaming) which are most often separated in both academic and popular discourses of new media use. This is not because the concepts and rhetoric supporting these representations are easily collapsed, nor is it because they amount to the same thing; rather, it is because they both work in similar ways to establish digital and interactive media as forming 'virtual' worlds that are equated with the conceptual 'unreality' of physical drug use.

\section{The diction of addiction and the digital}

According to Anne Federwisch (1997), the first identification of the phenomenon of 'cyber addiction' was made by New York psychiatrist Ivan Goldberg who identified groups of people abandoning family obligations to stare at the computer screen. Apparently Goldberg's statement was a spoof on contemporary North American culture's fascination with addictive behaviours (Federwisch, 1997). 
However, the idea of internet and electronic gaming addictions soon became a field - including academic research, popular cultural intiturich production, judicial institutions and news media. What began as a joke has been transformed into a number of discursive formations that weave together the digital and the behavioural. What the identification of digital addiction does, effectively, is anply a set of connotations under the 'drug'-related signifier 'addict' to a new set apply a set of connotations under the 'drug'-related signifier 'addict' to a new set of behaviours, usually having no special or direct relationship with drugs (whether legal or illicit) or alcohol. Sex addiction, gambling addiction, workaholism, addiction to serial monogamy, addictions to violence or physical exercise, and compulsive 列 eating have all been ides ox frequent and/or unusually excessive activities in such a way that reduces a set of frequent and/or unusually excessive activities to a single form and cause, relegating the object that is utilised compulsively to danger, an unknown or a moral concern. The use of new media forms, particularly aspects of internet use and electronic games, has likewise been subject to this identification in what appears to be a continued 'netting' of behaviours under this one signifier.

Chemical drug addiction is often associated with moral disorder, a physical ailing a social failing a bodily disease the symptom of which is substance abuse failing, a social fal by Alcoholics Anonymous who evoke the figure of the forever or as an in 'recovering alcoholic'), or as an infectious disease that must be contamed or monitored for fear of spreading addiction from one body to another (Lart, 1998: 61) Variously one or several of these concepts can be used in the rhetoric of digital Varion the frequent internet user or game-player as an addict. Often this is seen simultaneously as both a psychological disorder and in addict. Often this is seen simultan to which one is addicted - digital media in this case (e.g. Holliday, 2000: 10)

I have no expertise in the neurological sciences, but I do want to give a brief description of physical drug addiction, as I understand it, since it differs markedly from both popular cultural representations of drug abuse and from the discourses of addiction as applied to the non drug. The body's drug receptors are molecules prestes its present at the ability of nerve cells to fire and produce various body chemicals associated with pleasure. Different drugs are understood to react with different receptors - for example, specific opiate receptors in the case of opioid drugs. Drugs are eventually metabolised sy by the body, brokn down by enzym the body through urine or sweat. Although biological accounts of addiction to most chemical drugs agree that biologic, psychosocial and cultural variables need to be taken into account, prolonged use of drugs is predominantly understood to alter therstom of receptors such that persistent and addictive permanently or damage the sysem of use is necessary for receptor finction (Zweben and Payte, 1990). This account is merely one particular narrative or language of addiction and, from the perspective of cultural theory, none of this is to suggest that what constitutes a drug is necessarily clear or final, nor that biological responses to drug-like substances are universal or necessarily will ever be fully mapped.
Much of the problem with the application of drug rhetoric to digital media is that it fails either to take into account the more nuanced neurobiological narratives around the permanent and physical alteration of the body's receptors, or to query how the very notion of 'drug' can be applied to digital media. Kimberly Young, whose widely distributed and frequently cited study Caught in the Net (1998) is a popular example of scandal and moral panic writing, utilises the pop rhetoric of chenical drug addiction, and indeed 'modelled her clinical criteria of Internet addiction on psychoactive substance dependency' (Griffiths, 1998: 68). Certainly her writing is filled with comparisons reductively suggesting that internet addiction is not different from 'alcoholism, chemical dependency, or addictions like gambling and overeating' (Young, 1998: 7). Young explains the frequent use of the internet by undergraduate students as the result of a higher legal dninking age (21 in much of the United States), suggesting that the internet becomes a 'substitute drug of choice: no ID required and no closing hour' (Young, 2003). She refers to internet addiction as an epidemic (Young, 1998: 5), much as the moral panics around drug use among youth invoke concepts of spread, contamination and conformity. She also suggests that internet users experience various 'mood states derived from such on-line stimulation [ranging] from reduced loneliness, improved self-esteem, and euphoria' (Young, 1997).

Importantly, Young does recognise that this is the application of addiction rhetoric to a non-drug dependence phenomenon. However, rather than establishing too close a set of parallels between the internet as 'drug' and drugs themselves, she works through a notion of 'addictive behaviour' by drawing on previous writings which have looked for commonalities between chemical drug dependence and habits such as compulsive gambling, chronic overeating, sexual compulsion and obsessive television viewing. For Young, it is the 'feeling' experienced that is addictive rather than the digital media itself (Young, 1998: 17). However, in relying on a pedestrian account of technological determinism, her claim locates itself in an idea that exposure itself to the internet is the root cause of the addiction, much as two or three shots of heroin or a couple of days of smoking are understood to bring on physical dependence: 'Most internet addicts, you'll recall, get hooked within months of first venturing on-line.' (Young, 1998: 97) The terminology used in her theorisation and subsequent 'recovery programme' also works to solidify a comparison between the digital and the chemical drug: 'hooked', 'denial', 'relapse', 'triggers' (Young, 1998: 2003).

The application of drug rhetoric to non-chemical behaviours and activities works to constrain a complex set of behaviours, patterns and analyses within a narrative of addiction that on the one hand suggests frequent or compulsive use is a weighted negative and on the other defines the artefact used as dangerous, negative or, as with certain chemicals, the 'cause' of addiction. In an interview on the cultural semiotics and connotations of drug use and dependence, Jacques Derrida refers to a notion of the 'diction' of 'addiction' as a set of significatory characteristics that are applied to drug users and effect connotations which bind the applicant within particularly fixed ideological and political valencies (Derrida, 1995). I want to return to Derrida's diction of addiction at the end of this paper, but it is important 
at this stage to note that the application of the addiction metaphor constrains behaviour, performatively producing behaviour and establishimg the 'digital world' as an unnatural, unreal, dangerous 'substance'.

\section{Online addiction}

According to Kimberly Young's research, 5-10 per cent of internet users are addicted - she concludes therefore that five million internet users are addicts. Having utilised user responses, she is able to articulate a particular narrative of online addiction, but of course in methodological terms her estimate of addiction rates has little legitimacy, and her concern that 97 per cent of her respondents spent more time on the internet than they might have liked tells us little about overall estimates of addiction. While Young's study has been criticised for its reliance on a self-selected sample replying to advertisements posted on usenet groups and internationally distributed newspapers (e.g. Griffiths, 1998; Grohol, 2000: 139), and might be further criticised for her attempt to use such a sample to estimate rates of internet addiction among a much broader demographic, it is her production of the normative and its location in the 'real' that has much broader implications for the idea of digital addiction.

Young sees the space of digital communication, digital textuality and imteractive performance as a world of 'make-believe' (Young, 1998: 21), which has dangerous cons distinction between 'real life' and 'virtual life' behaviour, she validates the real over the digital. Her concern is that, in spending time online, inhibitions are broken down and people will type 'words you wouldn't dream of saymg im your real life' (Young, 1998: 21). She claims that heavy imternet users neglect their 'real' lives: 'other family members and friends of imternet addicts lament the addict's total loss of interest in once-treasured hobbies, movies, parties, visitimg friends, talking ove dinner' (Young, 1998: 7). Rather than examining the ways in which the availability of online communication might afford opportunities for new social and personal of online com determinist approach that understands the internet as foisted on users rather than as produced through various cultural demands for new forms of imteractive communication, she bemoans the ways in which it distracts from the 'real':

Mary Lou is neglecting her husband and four kids, Bob's children can't get through to him, and Jennifer disappeared so far into the black hole of cyberspace that her mother worries that she won't get back ... Brenda and Bob are withdrawing from those around them to hang out with their fiends on the internet, much as alcoholics prefer the company of fellow drimkers who will support them in their addictive behavior. (Young, 1998: 16-17)

The validation of the real as normative over digital communication shuts down the possibility of addressing the ways in which arrangements for conductimg communication friendships, learning infornation access, entertainınent and leisure activities might be diverse, and works to establish the physical and local as the real, while viewing the social space of the internet as the 'virtual' or the 'pseudo'
- a lesser form of communication experience that is addictive by virtue of its virtuality.

For Young, it is not only the predication of a virtual world that is problematic but the amount of time spent engaging with it, communicating through it or utilising it for some purpose. She separates the experience of the internet from other experiences in which time is wasted or lost or 'flies' - for example, talking on the telephone, evenings out with friends. For her, time spent online is the major criteria to indicate addiction. As she puts it: 'In my survey 97 per cent of all respondents reported that they found themselves spending longer periods of timeon-line that they intended.' (Young, 1998: 36) Television and radio are not treated to the same concerns around interactivity because they are not viewed as an ingress into a virtual or cyber world. I would suggest that they in fact do invoke imaginary spaces - a point Joshua Meyrowitz makes in invoking the conceptual difference between physical place and communicative social space utilised through television and telephone (Meyrowitz, 1997). These are exempt from claims of addictiveness, then, not because they differ substantially - they are all media and communications forms with varying levels of interactivity - but because television and radio are structured around scheduling and time.

There are three further methodological or conceptual problems in Young's work that contribute to a reductive view of the internet as addictive. The first of these is that she collapses all internet usage into one form or into several related activities that centre on one form and one use. Young relates the chat room as the hub of the internet:

the path that leads to obsessive involvement with the internet community usually leads directly to the center of chat rooms and interactive games. Once you get there, you rapidly immerse yourself in this community despite its limitations, its pitfalls, and its addictive nature that pulls you away from your actual life and the people and predicaments you should be facing. (Young, 1998: 114-15)

What is ignored here is the multiplicity of sites, uses, forms of information and activities - indeed, the very multiple structure of the internet as a combination of usenet newsgroups, email use, chat use, websites and interactive games is ignored.

Second, rather than viewing the use of digital media as diverse, Young works through a severe and strict technological deterininist method - the 'blame' for internet addiction lies in the dynamic between the addictive potential in all users and the presence or existence of the internet. For Young, repressed and buried emotions are brought out in accessing the internet, and she is particularly interested in the ways in which playing violent games draws out repressed childhood resentments of being ignored, causing subsequent violence to be expressed in 'real life' (Young, 1998: 73). The internet here is understood as an 'invention' that will have significant effects on human behaviour, not as emerging within and through culture and being accessed as a result of particular cultural demands and desires, as a culturalist model would have it (Williams, 1990). In Young's discourse, the internet is alien to culture, and comes to destroy the civilising processes that are already in place. 
This leads to a third point: the ways in which Young presents particular social angements not only as normative, but as desirable. In favouring her conception of 'real life' over the mythical 'virtual', she predicates not only physical and geographically local relationships over communication, entertainment and informationseeking in digital forms, but celebrates the suburban and conservative family as social unit to be hermetically sealed off from alternative friendships, relationships social unit to be hermetically sealed off from altentive friendships, relationships and communicative practices that occur through digital means and across distances. She is concerned with what access to the internet does to people like Jeanne:

a 34 year-old wife and homemaker from South Carolina. By appearances, Jeanne had a perfect life; an attentive husband, a nice house, two healthy toddlers, a few good friends through her church. (Young, 1998: 18)

After use of the internet, Jeanne 'began sharing her most personal thoughts and intimate details of her life' with online friends ('not her husband or real-life friends') and soon began an online rendezvous with another man, exchanging erotic messages as cybersex. 'Through the internet, she had formed a bond so close that she tossed aside a 15-year marriage.' (Young, 1998: 18-20) Rather than examining the ways in which a marriage-interrupting bond formed through online communication migh not be dissimilar from those formed in other social experiences, the statement here is that access and frequent use of the internet destroyed the normative family which is given here as the 'perfect life'. Likewise, players of MUD interactive games are seen to be ignoring their real families who 'are in the next room singing and laughing with holiday merriment' (Young, 1998: 89), and Young bewails the and laun fact that families hardly ever eat together possibility of viewing the internet as emerging culturally alongside broad sociocultural changes, including variations in the perception of family, friendship and ways in which leisure time is legitimated; instead, it is presented as an 'alien' substance facilitating the breakdown of lived culture per se.

\section{Electronic gaming addiction}

While a markedly different media form from the internet, electronic gaming is likewise subject to accusations that it is inherently addictive, which works to locate the activity of gaming as a dangerous yet virtual substance separated from the cultural. Electronic games, computer games, arcade games - all have been subject to various ideological positions on their social valency, the promotion of violence and ideas around the loss of 'self' in the notion of the collapse between self identity and game-character identity (e.g. Slater et al., 2003; Funk et al., 2003). Indeed, many of the arguments in public discourse which attempt to assert that electronic games are the cause of violence often cite, or at least imply an idea of, addiction to electronic gaming as a significant factor working to desensitise players to vionce (Plusquellec, 2000). Academic research into electronic gaming and addiction has of ten pointed to electronic gaming as an addictive activity (Wolf, 2001: 4), although this view is also frequently denounced as overly reductive. Nevertheless, a certain wariness at denouncing gaming as addictive is discernible, frequently by making the point that, although there is nothing addictive in games themselves, they are subject to 'excessive use' leading to personal 'isolation' from social activities (e.g. Plusquellec, 2000). As with the frequent collapse of internet and online communicative and media forms into a single phenomenon, electronic gaming activities tend to be relegated to just one form, usually under the heading 'video games'. There is, of course, an array of different gaming genres, from action-adventure, god-games and first-person shooters to fantasy (Berger, 2002: 12-13), and significantly diverse forms of utilisation of gaming, from solo play on a computer or gaming platforn such as the PlayStation 2 or the X-Box, to online gaming (Humphreys, 2003). This collapse of gaming serves the accusation of addiction by allowing critics to ignore the vast array of uses, types and pleasures that inspire ongoing game-play in diverse ways.

Electronic gaming is a markedly different category of digital media and entertainment from most online use (with the exception of online games), although one marked similarity - which I will discuss in more detail in the next section relates to the ways in which both gaming and the internet are seen to establish a separate, dichotomous and 'virtual' imaginary space in opposition to real-life activities and real play. Nevertheless, gaming in the popular imaginary is often seen to be diametrically opposite to the internet, particularly in celebrationist accounts of online interactivity. For Lister et al. (2003), a dichotomy between computer-mediated communication forms (CMC) and video games is supported by several of the following binaries: creative content versus mindless entertainment; adult users versus youth consumers; fluid identity versus hypermasculinity; sociality versus commodified space; tool versus toy. More importantly, where the internet is sometimes seen as positively immersive, gaming immersion is rewritten as addiction (Lister et al., 2003: 263). What also appears to differentiate the video game addict from other 'digital addicts' produced within popular culture is the differing weighting given to the concept of the addict as a 'social menace'. While online internet addicts are produced within a discourse of liberal ego-psychology and popular neurosis, the addicted gamer is seen as a low-class, proto-violent, addicted and dangerous kid (Beavis, 1998), learning to express repressed anger and aggression (Young, 1998: 73), sociopathically isolated (Thompson, 2002: 28) and potentially capable of perpetrating another Columbine High School shoot-out (King and Borland, 2003: 175). Unlike writers such as Young, who lump games and online use together and read all digital immersion as addiction, there is clearly a strand in popular discourse that seeks to celebrate one over the other, marking only electronic games as addictive. Two reasons are significant: the greater association of gaming with youth culture; and the interactive goal-seeking form that constitutes much of game-play.

Although it is certainly the that younger persons, children and teenagers, make up a significant proportion of the lenown game-player demographic (Latham, 2002: 47; Buchanan, 2004: 143), it is also the case that games are becoming a popular lifestyle choice among adults (Newman, 2002), particularly since the marketing of Sony's PlayStation 2 and the Microsoft X-Box consoles. Nevertheless, the nexus between youth, gaming and addiction continues to be posited in both popular discourse, alarmist moral panics around game culture and some academic writing Popular concerns that children are now playing digital games rather than with 
'physical' toys such as building blocks or footballs are made often by opinion'physical' toys such as building blocks or foothal are made often by opinionmakers and politicians - and indeed a stement computer gaming recently formed part of the election platform of Australian Labor Party leader Mark Latham (Hudson, 2004). A recent opinion-editorial in the Melboume (Australia) newspaper 7he Age reaffirmed the continuing separation in value of reading literature from electronic gaming as activities appropriate for children. Chris Bantick's 'Why Computer Games Should Worry Parents' (2002) suggested three problems with younger persons playing computer games: (1) games usurp the creativity involved in playing with Lego building blocks; (2) games along with DVDs distract from reading; and (3) games are compulsive and addictive. What is striking yet representative about this particular piece is that it continues an artificial high/popular culture division, and locates the alleged addictiveness of games within an anxiety over interactive, participatory and immersive formats that are understood to compete with the conceptual representation of high art that is embodied in the non-interactive print book. Compulsive reading, then, is exempt from calls of addiction - though there may well be grounds for the application of addiction rhetoric to some readers - because it bears no resemblance to or association with the less 'legitimate' form of new media arts.

There remains at play, then, a logic which suggests that frequent use of games and digital media is addictive because it is used by youth. This is part of what Mark Davis (1997) identifies as cultural generationalism in the West that denounces the practices, behaviours, concerns, ideas and pastimes of youth and children while nostalgically venerating those of the recent past. Certainly Bantick's concern that nostalgically venerating those of the recent past. Certain displaced in favour of electronic games and online entertainment is rooted in a celebration of the popular toys of a baby boomer generation over those used by people currently under 30 . At the same time, it is fed by a concern around the toys of the 'real world' over those available in digital formats - he around the toys of the 'real world' over those available in dictar a concern that it may lead to an 'addiction to electronic stimuli at the expense of the physical'. With this set of connections between youth and digital media, and given the already packaged discursive linkage of youth and drugs (Redhead, 1997: 58-59; Murji, 1998: 78), associating youth and digital cultures in the rhetoric of drug addiction and risk finds a moral basis in a set of panics around the protection of children and younger persons.

A further way in which the signifiers addiction and electronic gaming are frequently conflated in alarmist responses to game culture is through the amorphous and undecidable nature of the games as the 'text' and/or 'play'. This is to continue the misreading of immersion or interactivity as addiction, but it is a perception that is legitimated by the subsequent goal-seeking and anticipation that constitute this form of digital interactive entertainment. Games are a form of digital media that form Kurt Squire's terms, a hybrid of text and interactive play (Jenkins and Squire Kurt Squire's terms, a hybrid of text and interactive play (Jenkins and Squire 2002: 65). Play, as Huizinga pointed out in his Homo Ludens (1949), is virtually always conditioned by tension through goal-seeking (1949: 10-11). As he elaborat

There is always the question: 'will it come off?' This condition is fulfilled crosswords, diabolo, etc. Tension and uncertainty as to the outcome increase enormously when the antithetical element becomes really agonistic in the play of groups. The passion to win sometimes threatens to obliterate the levity proper to a ganie. (Huizinga, 1949: 47)

His mobilisation of the concept of passion is highly significant here: many of the fears mvoked around violence and games and around electronic gaming addiction have to do more with a 'passion' for the game, for game-play and for achieving a success $m$ the outcome of meeting a goal. Such goal seeking across many games requires familiarity with the game, its environment and its internal narrative structures; it requires training and practice; it requires dedication - whatever the personal or social value in gameplay, it remains that in the discourses of moral panics passion is rewritten as addiction, supported by the witness of a player's time and dedication. It is poigulant to note that a passion for career, a sporting activity or even legitimate politics is seen as healthy, whereas passion for that which is relegated to the digital is understood as dangerous or addictive.

\section{Digital/real and the discourse of the addict}

It follows within the diction of addiction that there is an addiction of the 'self' or the body or the personality or some other facet of performative selfhood to something. While drugs are seen to be an ingested physical supplement (a pill, a powder, a liquid) penetratimg the body through the hypoderinic or otherwise consumed, it is what drugs represent - 'effect' - that is considered virtual, unreal, without reality or outside of reason. Addiction is generally given in terms of an addiction to the unreal, something that is a lesser than that which is categorised as natural, righteous, appropriate, beneficial. In the rhetoric of digital addiction, both game-play and online internet experience are given as the unreal or the virtual, not because of something that takes it outside of physicality and normal behaviour, or because they are technologies which are relatively new, but because the narrative, communicative, articulable 'worlds' that are evoked interactively have no physical substance - they are represented as a substance of unreality. Both the real and the virtual, as a number of writers have pointed out, are conceived simultaneously, such that both are represented as pure, self-sufficient and separate. Both technology celebrationists and luddites view the virtual scape of video games, internet usage and other VR_related technologies as the realm of order and a new world, posthuman, postculture. As Elizabeth Grosz puts it:

Whereas many see in VR the ability to aspire to God-like status, to create, live in, and control worlds, to have a power of simulation that surpasses or bypasses the uncontrollable messiness of the real, others (sometimes even the same writers) revile and fear VR's transformation of relations of sociality and community, physicality and corporeality, location and emplacement sexuality, personal intimacy, and shared work space - the loss of immediacy, of physical presence ... Unashamed apologists of cybertechnologies and nostalgic Luddites yearning for days gone by see VR as a powerful force of liberation and a form of everencroaching fascistic control, respectively.

(Grosz, 2001: 77) 
The salient point here is whether those who celebrate or denounce new media forms from within a binary concept of real/virtual all see a transformative potential for the real and the 'real self (whatever that might yet come to mean) im the encounter with the virtual, such that repetitive, frequent, passionate and even obsessive encountering of digital media sparks an anxiety that equates the virtual with the unreal drug. Digital media and games are understood as addictive not because they are compulsively used but because, as 'unreal', they are like drugs, and thereby become subjected to a discourse of drug addiction. For Derrida, we reject the drug addict because:

$\mathrm{He}$ [sic] cuts himself off from the world, in exile from reality, far from objective reality and the real life of the city and the community ... drugs, it is said, make one lose any sense of true reality. In the end, it is always, I think, under this charge that the interdiction is declared. We do not object to the drug user's pleasure per se, but to a pleasure taken in an experience without truth. (Derrida, 1995: 235-36)

Although I am arguing here that the connection between drug addiction and digital addiction is more than a metaphorical comparison - for both are rooted $\mathrm{m}$ a perception of what it is that constitutes 'real' - a simple insertion of the signifiers 'game' or 'internet' in place of drugs in the above quote mdicates neatly the ways in which digital addicts are produced in contemporary culture. Because they are not within the loowledge of objective reality, digital commurucations and interactive entertainments are seen as a pleasure experienced 'without truth'. The digital world is seen, then, as a paradox that makes it foreign to the representation of the 'real' - it is both ordered and chaotic. In the rhetoric of digital addiction, digital media are seen as chaotic, neither structured around time nor centralised; categories are mixed, cross-bred, hybridised and blurred (Gaillot, 1998: 44). Indeed, Young's connotative terminology for online media bespeaks a certam messimess $\mathrm{m}$ its unreality: it is 'make believe' (Young, 1998: 21), it will 'lure' the user into a 'world without limits [that is] multidimensional' (Young, 1998: 23), it asks for time to 'trudge through the garbage swirling in the whirlpool of info.glut' (Young, 1998: 38). At the same time, digital forms are viewed as being too-structured - a sealed world, such as the narrative space of an interactive game that no matter how complex, has a structure that is over-determined and simplistic (Newman, 2002), a set of rules that one can imagine breaking but which are impossible to defy (Humphreys, 2003: 84; Beavis, 1998), and lacks the genuinely random pleasure of 'real-life' play and communication.

The fact that the work of Young and others on digital addiction is driven by the ideological position that digital texts and communications possess less value than 'physical' artefacts and relationships conducted in face-to-face capacities poimts to the fact that addiction is located in the digital viewed as a 'negative' space, negative spaces being addictive by nature in her view. But, for Young and for the diction of drug addiction, the object of addiction is neither that which is consumed nor that which influences. Rather, both drugs and the digital are seen to pervade the mythical naturalness or nature of the user. As Derrida puts it:
By the grace of the technical or artificial, and ever-interiorizing violence of an injection, inhalation, or ingestion, by taking into my self, inside myself a foreign body, or indeed a nutriment, I will provoke a state of productive receptivity ... (Derrida, 1995: 240-41)

For Young, digital addiction is seen to 'penetrate' like an 'epidemic' (Young 1998: 5), a foreign and (to her, at least) unknowable or unreasonable substance that comes to infiltrate her ideal of the natural body. The factor that comes into play here relates to the 'fear' of digital forms, not because of a cultural fear of new technologies or ludditism, but the result of the available politics of new media forms. As John Downing has pointed out, it is possible to typify 'mainstreammedia' as focused on hegemonic integration and alternative-media 'with their frequent focus on challenging the structures of power' (Downing 2003: 626). If the familiarity of the ideologically hegemonic brings it into the 'real' - the production of our everyday realities - then that which challenges it is relegated not only to a place of fear and danger, but to a virtuality which is exacerbated in the contemporary cultural imaginary by its frequent digital form and its accessibility through the screen, keyboard, joystick and other accoutrements of cyber virtuality. Alternative media and alternative, structure-challenging politics become thus associated with the digital world, and relegated to a space on the other side of the artificial real/virtual binary. The terminology of escapism into digital media and communications - escape from 'the real' - is also dominant in addiction studies and panics about digital addiction (Binaisa, 2002: 45; Reid, 1998: 29). What occurs in a deconstructive understanding of digital addiction, then, is that one takes the 'virtual' inside the 'real' body or identity in order to escape the real.

Thinking about digital addiction leads to thinking about the relationships between new media and sociality through breaking down the artificial distinction between the real and the virtual that is so pervasive throughout both celebrationist and alarmist discourses of new media. Grosz and other writers point out that what the world of the digital does best is 'reveal that the world in which we live, the real world, has always been a space of virtuality' (Grosz, 2001: 78). It is thus important to look at how addiction to the virtual, digital worlds of the internet and the electronic game come to inflect the ways in which we think about and represent addiction otherwise. Simon Cooper perceives the idea of addiction to communications technologies as an addiction to sociality (Cooper, 2002: 3-4), thereby drawing back from the artificial separation of real space and digital space. It is only in rejecting the distinction and looking to how the concepts of the virtual teach us what it is that might constitute 'real' that we can move beyond the reductive arguments to whether or not digital media are addictive and consider the more important issues, not as to how or why they might be compulsive for some users or players, but what it means that this form of compulsion emerges at this time in contemporary culture. 
References

The Age 2004, 'Online Addicts Abandon the Real World', 12 January, www.theage.eom.au/articles/ 2004/01/12/1073769485753.html

Bantick, Chris 2004, 'Why Computer Games Should Worry Parents', The Age. 15 January, www.theage.com/au/articles/2004/01/14/1073877896185.html

Beavis, Catherine 1998, 'Computer Games: Youth Culture, Resistant Readers and Consuming Passions', paper presented at Research in Education: Does it Count - Australian Association for Research in Education Annual Conference, 29 November-3 December.

Berger, Arthur Asa 2002, Video Games: A Popular Culture Phenomenon, Transaction Publishers, New Brunswick and London.

Binaisa, Mazzi 2002, 'All Clicked Out', in L. King (ed.), Game On: The History and Culture of Videogames, Universe Publishing, New York, pp. 44-45.

Buchanan, Kerry 2004, 'Video Games: Ritual or Rebellion?', in L. Goode andN. Zuberi (eds), Media Studies in Aotearoa/New Zealand, Pearson, Auckland, pp. 135-45.

Cooper, Simon 2002, Technoculture and Critical Theory: In the Service of the Machine? Routledge, London and New York.

Davis, Mark 1997, Gangland: Cultural Elites and the New Generationalism, Allen \& Unwm, Sydney.

Derrida, Jacques 1995, 'The Rhetoric of Drugs', trans. M. Israel, in Elisabetb Weber (ed.), Points ... Interviews, 1974-1994, trans. Peggy Kamuf et al., Stanford University Press, Stanford, CA, pp. 228-54.

Downing, John D.H. 2003, 'Audiences and Readers of Alternative Media: the Absent Lure of the Virtually Unlenown', Media, Culture \& Society vol. 25 , no. 5, pp. $625-45$.

Egli, Myers 1984, 'The Role of Video Game Playing in Adolescent Life: Is There a Reason to Be Concerned?', Bulletin of the Psycloodynamic Society, vol. 22, no. 4.

Federwisch, Anne 1997, 'Intemet Addiction?', Nurseweek, 8 August, www.nurseweek.com/features/ 97.8/iadcthtml

Funk, J.B., Buchman, D.D., Jenks, J. and Bechtoldt, H. 2003, 'Playing Violent Video Games, Desensitization, and Moral Evaluation in Children', Journal of Applied Developmental Psychology, vol. 24 , no. 4 , pp. $413-36$.

Gaillot, Michel 1998, Multiple Meaning: Teclmo: An Artistic and Political Laboratory of the Present, Inter views with Jea nLuc Nancy \& Michel Maffesoli, trans. W. Niesluchowski, Ėditions Dis Voir, Paris, pp. $17-39$.

Griffiths, Mark 1998, 'Internet Addiction: Does It Really Exist?', in J. Gackenbach (ed.), Psychology and the Internet: Intrapersonal, Interpersonal, and Transpersonal Implications, Aeademic Press, San Diego, pp. 61 75 .

Greenberg, J.L., Lewis, S.E. and Dodd, D.K. 1999, 'Overlapping Addictions and Self-Esteem Among College Men and Women', Addictive Behaviors, vol. 24, no. 4, pp. 565..71.

Grohol, John M. 2000, 'Review: Caught in the Net', Addiction, vol. 95, no. 1, pp. 139-40.

Grosz, Elizabeth 2001, Architecture from the Outside: Essays on Virtual and Real Space. MIT Press, Cambridge, MA.

Holliday, Heather 2000, 'Hooked on the 'Net', Psychology Today, vol. 33, no. 4, p. 10

Hudson, Phillip 2004, 'Latham's Book Pledge', The Age, 1 February, www.theage.eom.au/articles/ 2004/01/31/1075340895376.html

Huizinga, J. 1949, Homo Ludens: A Study of the Play-Element in Culture, Routledge \& Kegan Paul, London.

Humphreys, Sal, 2003, 'Online multi.user games', Australian Journal of Communication, vol. 30, no. 1, pp. 79-91.

Jenkins, Henry and Squire, Kurt 2002, 'The Art of Contested Spaces', in L. King (ed.), Game On: The History and Culture of Videogames, Universe Publishing, New York, pp. 64-75.

King, Brad and Borland, John 2003, Dungeons and Dreamers: The Rise of Computer Game Culture, McGraw-Hill/Osborne, Emeryville, CA.

Watha Rob 2002, Consuming Youth: Vampires, Cyborgs, \& the Culture of Consumption, Chicago University Press, Chicago.

Uart, Rachel 1998, 'Medical Power/Knowledge: The Treatment and Control of Drugs and Drug Users', in Ross Coomber (ed.), The Control of Drugs and Drug Users: Reason or Reaction Hach, Amsterdam, pp. 49-68.

(ter, Martin, Dovey, Jon, Giddings, Seth, Grant, Iain and Kelly, Kieran 2003, New Media A Critical Introduction, Routledge, London and New York.

Y. Jitz, Joshua 1997, 'The Separation of Social Space from Physical Place, in T. O'Sullivan and Yuri, Kewkes (eds), The Media Studies Reader, Edward Amold, London, pp. 45-52.

(ed) 7 Cont 'The Agony and the Ecstasy: Drugs, Media and Morality', in Ross Coomber pp. $69 \_85$.

作 Relationships in Videogames', Game Studies, vol. 2, no. I.

Archives de Pediatrie Virtual Worlds Threaten Children's and Teenagers' Mental Health?' no. 2, pp. 209-10.

Rhead, Steve 1997, Subculture to Clubcultures: An Introduction to Popular Cultural Studies, Blackwell, Oxfiord.

Reid, Elizabeth 1998, 'The Self and the Intemet: Variations on the Illusion of One Self, in J. Gackenbach (ed.), Psychology and the Internet: Intrapersonal, Interpersonal, and Transpersonal

Ther, M.D. Henry, $\mathrm{K}$ L, Swaim, R.C. and Anderson, L.

Aggressiveness in Adedia Content and Aggressiveness in Adolescents: A Downward Spiral Model', Communication Research, vol. 30,

ydney Morning Herald 2004, 'Online Addicts Abandon the Real World', 12 January, WW.Smh.com.au/articles/2004/01/12/1073769461598.html

The Williams,

Teche Rociety' in T. Bennett (ed.), Popular Fiction: Technology, Ideology, Production, Reading, Routledge, London, pp. 9-22

Yolf, Mark J.P. 2001, The Medium of the Video Game, University of Texas Press, Austin, TX. In, Kimberly S. 1997, 'What Makes the Internet Addictive: Potential Explanations for Pathologica Internet Use', paper Presented at the $105^{\text {th }}$ Annual Conference of the American Psychological Association, 15 August, http://netaddiction.com/articles/habitfonning.htm

- 1998, Canght in the Net: How to Recognize the Signs of Internet Addiction - and a Winning Strategy for Recovery, John Wiley \& Sons, New York.

2003, 'Surfing Not Studying: Dealing with Internet Addiction on Campus', 2.th:/hetaddiction.com/articles/surfing_not_studying.htm

(1990, 'Methadone Maintenance in the Treatment of Opioid Dependence', The Western Journal of Medicine, vol. 152, no. 5, pp. 588-99.

Rob Cover is a Lecturer in Media Studies at Victoria University of Wellington, New Zealand. He researches and publishes on media theory and queer theory, with specific interests in new media and identity, performativity in horror film and television, and the sociality of electronic gaming. 